\title{
RENCANA KEBIJAKAN ZONASI WILAYAH PESISIR DAN PULAU- PULAU KECIL DI PROVINSI BALI
}

\author{
Muhammad Ramdhan ${ }^{1}$, August Daulat ${ }^{1}$, Nasir Sudirman ${ }^{1}$ \\ ${ }_{1}^{1}$ Peneliti pada Pusat Riset Kelautan, BRSDM - KKP \\ Jln. Pasir Putih 1 Ancol Jakarta; Telp/fax : +62 2164711583 \\ Email: m.ramdhan@kkp.go.id
}

\section{RINGKASAN}

Wilayah pesisir dan pulau-pulau kecil telah berkembang menjadi pusat-pusat pertumbuhan ekonomi di Indonesia. Untuk itu tiap provinsi diwajibkan untuk memiliki suatu Rencana Zonasi Wilayah Pesisir dan Pulau-pulau Kecil berdasarkan Undang-Undang Republik Indonesia No.23 tahun 2014 tentang Pemerintahan Daerah Pasal 14. Dokumen Rencana Zonasi Wilayah Pesisir dan Pulau-pulau Kecil untuk suatu provinsi memerlukan deskripsi potensi sumber daya pesisir dan pulau-pulau kecil beserta kegiatan pemanfaatannya, isu-isu strategis wilayah, tujuan, kebijakan dan strategi pengelolaan wilayah pesisir dan pulau-pulau kecil, rencana alokasi ruang, peraturan pemanfaatan ruang dan indikasi program. Tulisan ini akan mendeskripsikan bagian dari rencana kebijakan zonasi di wilayah perairan pesisir Provinsi Bali.

Kata Kunci : Provinsi Bali, Wilayah Pesisir, Rencana Zonasi, Pengelolaan laut

\section{PERNYATAAN KUNCI}

Provinsi Bali terdiri dari Pulau Bali sebagai pulau utama dan beberapa pulau kecil di sekitarnya merupakan satu kesatuan wilayah yang harus dikelola melalui pendekatan terintegrasi antara ekosistem darat dan ekosistem laut.

\section{REKOMENDASI KEBIJAKAN}

Kebijakan pengelolaan Wilayah Pesisir dan Pulau-Pulau Kecil (WP3K) merupakan tindakan yang diambil sebagai landasan untuk mencapai tujuan pengelolaan WP3K sehingga tercipta tatanan alokasi ruang yang teratur, aman, produktif dan berkelanjutan. Kebijakan pengelolaan WP3K Provinsi Bali, sebagai berikut :

1. Pengembangan dan pemantapan kawasan konservasi di wilayah pesisir dan pulau-pulau kecil sebagai prioritas alokasi ruang laut sebagai perwujudan pengelolaan berbasis ekosistem;

2. Pengarusutamaan nilai-nilai sosial, budaya, spiritual, dan kearifan lokal dalam pengelolaan WP3K;

3. Pencegahan, pengendalian, pemulihan dan rehabilitasi sumber daya pesisir dan pulau-pulau kecil secara terpadu; 
4. Peningkatan mitigasi bencana dan adaptasi perubahan iklim;

5. Optimalisasi pemanfaatan sumber daya pesisir dan pulau-pulau kecil berbasis kawasan secara terpadu dengan penguatan pada pemberdayaan masyarakat dan mendorong investasi pemerintah, masyarakat dan swasta secara merata antar wilayah;

6. Pengembangan sistem dan pendekatan pengelolaan WP3K secara terpadu;

7. Peningkatan aksesibilitas serta dukungan prasarana dan sarana dalam pengelolaan WP3K.

\section{PENDAHULUAN}

Wilayah pesisir dan pulau-pulau kecil Provinsi Bali mengalami perkembangan pembangunan yang pesat, baik secara langsung maupun tidak langsung bertumpu pada sumber daya pesisir dan pulau-pulau kecil. Wilayah pesisir dan pulau-pulau kecil telah berkembang menjadi pusat-pusat pertumbuhan ekonomi. Berbeda dengan daerah lainnya, pembangunan Provinsi Bali bertumpu pada sektor pariwisata sebagai sektor unggulan dan pengganda yang mempunyai keterkaitan erat dalam mendorong sektor-sektor lainnya seperti perikanan, transportasi, industri pengolahan dan jasa-jasa lainnya. Kontribusi sektor pariwisata melalui Penyediaan Akomodasi dan makan/minum bagi pembentukan nilai tambah perekonomian Provinsi Bali dalam periode 2011-2015 rata-rata 21,43\% pertahun dengan pertumbuhan 7,04\% pertahun (BPS 2017).

Sebagai pusat-pusat pertumbuhan ekonomi yang digerakkan oleh sektor pariwisata, pendayagunaan sumber daya alam dan jasa-jasa lingkungan pesisir dan pulau-pulau kecil juga cenderung akan berkembang pesat seiring dengan perkembangan pembangunan kepariwisataan nasional yang mengalami pertumbuhan positif. Pertumbuhan pasar pariwisata nasional terutama pasar Asia dan Pasifik cenderung akan terus tumbuh di masa yang akan datang sejalan dengan kemajuan teknologi informasi dan transportasi. Pada dekade 2006-2015, pertumbuhan kunjungan wisatawan mancanegara mencapai rata-rata 8,65\% pertahun dan wisatawan nusantara rata-rata 13,11\% pertahun (BPS 2017).

Pesatnya pembangunan di WP3K di satu sisi memberi kontribusi yang besar bagi peningkatan perekonomian wilayah namun di sisi lain muncul berbagai permasalahan yang kompleks antara lain kerusakan dan alterasi ekosistem pesisir, erosi/abrasi pantai, pencemaran perairan pesisir, berkurangnya habitat peneluran penyu, kemerosotan sumber daya ikan dan konflik pemanfaatan sumber daya pesisir dan pulau-pulau kecil. Berbagai permasalahan di atas merupakan dampak dari 
pengembangan wilayah pesisir dan pulaupulau kecil cenderung bersifat transformatif yang merubah bentang alam dan eksploitatif terhadap ekosistem pesisir. Wilayah pesisir dan pulau-pulau kecil juga masih menjadi kantong-kantong kemiskinan di Bali khususnya wilayah pesisir di luar Kota Denpasar, Kabupaten Badung dan Gianyar. Sementara itu, untuk mengoptimalkan pemanfaatan potensi sumber daya perairan pesisir melalui peningkatan investasi guna memperluas lapangan kerja dan kesempatan berusaha masih terhambat oleh kekosongan regulasi pemanfaatan ruang laut.

Di sisi lain pembangunan di WP3K tidak terlepas dari ancaman bencana pesisir dan dampak perubahan iklim. Ditinjau dari aspek geografis, geologis dan hidrometeorologis wilayah pesisir dan pulaupulau kecil Provinsi Bali merupakan salah satu kawasan rentan terhadap ancaman bencana alam seperti gempa bumi, tsunami, banjir, abrasi pantai, angin kecang dan gelombang badai pasang. Demikian juga bahwa wilayah pesisir dan pulau-pulau kecil Provinsi Bali rentan terhadap dampak pemanasan global dan perubahan iklim.

\section{SITUASI TERKINI}

Luas wilayah Provinsi Bali adalah $5.636,66 \mathrm{~km}^{2}$, secara administratif terdiri atas 8 (delapan) kabupaten dan 1 (satu) kota. Provinsi Bali memiliki wilayah pesisir sebesar $3.512,68 \mathrm{~km}^{2}$ atau $62,3 \%$ dari total luas wilayahnya, wilayah pesisir ini terdiri dari 7 kabupaten dan 1 kota serta 35 kecamatan. Luas perairan pesisir Provinsi Bali adalah $9.440 \mathrm{~km}^{2}$ dan panjang garis pantai lebih kurang $633 \mathrm{~km}$ (Gambar 1). Wilayah pesisir dan pulau-pulau kecil Provinsi Bali merupakan suatu sistem sumber daya alam dan lingkungan hidup berserta sistem sosial, budaya ekonomi dan pertahanan keamanan yang mempunyai peranan penting bagi pembangunan daerah dan nasional (BPS 2017).

Perairan pesisir Provinsi Bali merupakan area yang menghubungkan Samudera Pasifik dan Samudera Hindia dimana terdapat aliran massa air Arus Lintas Indonesia (Arlindo) atau Indonesian Through Flow (ITF) (Gordon 2012). Sebagai penghubung Samudera Pasifik dan Samudera Hindia menjadikan perairan pesisir Bali dan sekitarnya sangat mendukung keragaman ekosistem pesisir. Sekitar 75\% garis pantai Pulau Bali dan pulau-pulau kecilnya merupakan habitat terumbu karang. Bersama-sama dengan ekosistem mangrove dan padang lamun, ekosistem-ekosistem pesisir sangat mendukung tingginya produktivitas hayati perairan pesisir yang berkontribusi bagi perikanan dan pariwisata.

Kombinasi antara arus yang kuat dan morfologi dasar laut berupa cekungan dan palung serta tebing-tebing berundak dasar laut menyebabkan banyaknya muncul upwelling air dingin yang menjadi faktor 
kunci bagi habitat pelagik ekonomis penting, seperti ikan lemuru, tongkol dan cakalang. Sumber daya ikan pelagis ini menjadi tumpuan bagi nelayan tradisional yang jangkauan penangkapannya sangat terbatas hanya di perairan pesisir. Kondisi oseanografi yang demikian juga menjadikan perairan pesisir dan pulau-pulau kecil Provinsi Bali sebagai koridor migrasi berbagai jenis mamalia laut dan beberapa spesies genting seperti penyu, paus, lumbalumba, pari manta dan Mola-mola (Supriatna 2008). Jika dilindungi dan dikelola dengan tepat, perairan pesisir dan pulau-pulau kecil Provinsi Bali dapat menjadi kantong-kantong bagi kehidupan laut dan perikanan yang produktif serta mendukung pariwisata yang berdaya saing.

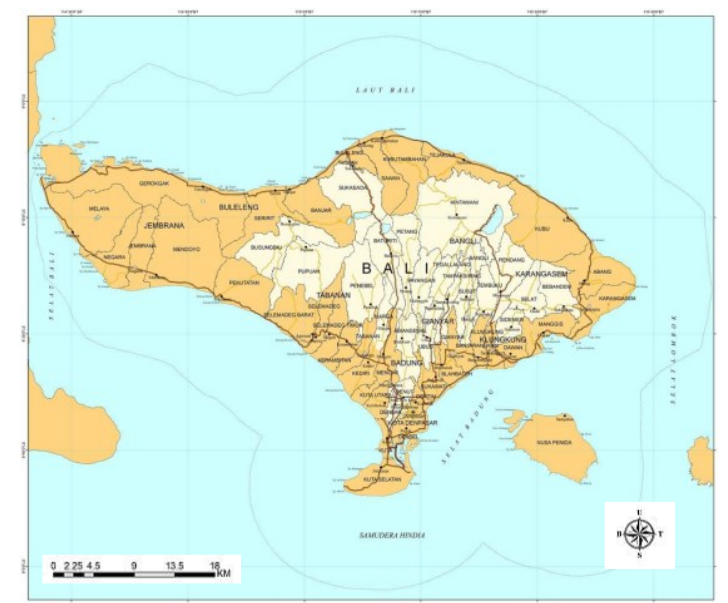

Gambar 1. Wilayah Pesisir Provinsi Bali, beserta garis batas perairannya

\section{METODOLOGI}

Metode dilaksanakan melalui desk study. Langkah pertama yaitu melaksanakan studi literatur sebagai awal atau referensi untuk penyusunan kebijakan pengelolaan WP3K di Provinsi Bali. Studi literatur dilakukan untuk mengumpulkan data sekunder awal terkait Kawasan Sarbagita. Data awal, meliputi: Peta dasar, yang berupa: 1. garis pantai; 2. bathimetri; dan 3 . batas wilayah Laut. Data tematik, yang berupa: 1. sistem jaringan prasarana Laut atau utilitas Laut; 2. bangunan dan instalasi di Laut; 3. oseanografi; $4 . \quad$ ekosistem pesisir dan pulau-pulau kecil; 5. wilayah pertahanan Laut; 6. sumber daya ikan; dan 7. pemanfaatan ruang Laut yang telah ada dan rencana pemanfaatan.

Selanjutnya pengumpulan data sekunder juga dilakukan melalui FGD. Focus Group Discussion (FGD)/Diskusi Tematik bertujuan untuk mengumpulkan data sekunder dari instansi dan stakeholders terkait seperti instansi pemerintah, dunia usaha, akademisi, dan perwakilan masyarakat. FGD/ Diskusi Tematik untuk kebutuhan penyusunan Rencana Zonasi WP3K, antara lain:

a. FGD Penentuan Nilai Penting dan Strategis Nasional

FGD ini bertujuan untuk menyepakati kegiatan-kegiatan di pesisir Provinsi Bali yang bernilai penting dan strategis untuk kepentingan nasional, batas wilayah perencanaan WP3K Provinsi Bali, serta perumusan tujuan, kebijakan dan strategi WP3K Provinsi Bali. Kegiatan bernilai penting dan strategis nasional/Obyek Vital Nasional adalah kawasan/lokasi, bangunan/instalasi dan/ 
atau usaha yang menyangkut hajat hidup orang banyak, kepentingan negara dan/atau sumber pendapatan negara yang bersifat strategis.

b. FGD/Diskusi Tematik sesuai kebutuhan untuk mempertajam dan memperoleh kesepakatan mengenai data tematik, antara lain:

1. Kedaulatan, Pertahanan dan Keamanan

- Pertahanan Keamanan (daerah latihan militer, daerah buangan amunisi/ranjau, pangkalan militer, dil)

- Obyek vital kedaulatan Negara, dll

2. Sosial Ekonomi

- Pelabuhan, alur pelayaran,

- Mineral, Migas, Telekomunikasi, dan Energi (kawasan pertambangan, pipa bawah laut, kabel bawah laut)

- Pariwisata

- Industri

- Program strategis nasional bernilai ekonomi,

- dll

3. Sosial Budaya

- Wilayah Masyarakat Hukum Adat

- Tradisi budaya maritim

- Daerah Benda Muatan Kapal Tenggelam

- Situs warisan dunia,

- dll

4. Sumberdaya Alam dan Lingkungan

- Ekosistem Pesisir
- Sumberdaya ikan

- Kawasan Konservasi

- Alur Migrasi Biota Laut

- Area Pemijahan (Spawning ground)

- Kawasan yang memiliki nilai sumberdaya signifikan dan sensitif

- Kawasan plasma nutfah

- Daerah rawan bencana dan pencemaran,

- dll

Klasifikasi Kawasan di wilayah pesisir dan pulau-pulau kecil disusun berdasarkan Undang-Undang Nomor 27 Tahun 2007 Jo Undang-Undang Nomor 1 Tahun 2014 tentang Pengelolaan Wilayah Pesisir dan Pulau-Pulau Kecil, dan penentuan arahan pemanfaatan alokasi ruang wilayah pesisir dan pulau-pulau kecil dilakukan melalui penentuan zona dan sub zona atau arahan pemanfaatannya pada masing-masing kawasan (Gambar 2).

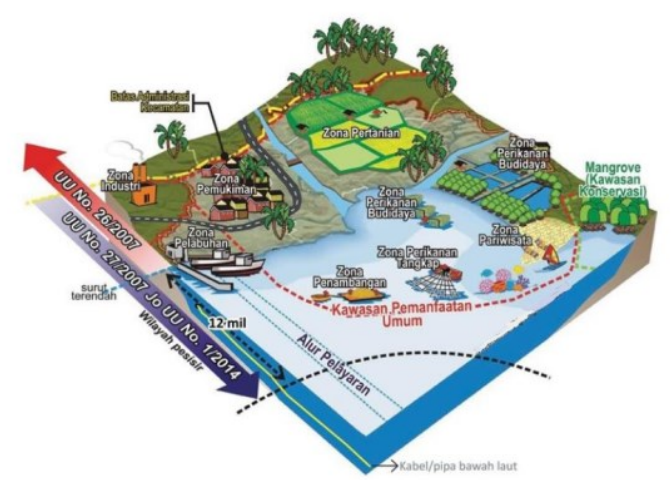

Gambar 2. Ilustrasi Pembagian Kawasan di Wilayah Pesisir dan Pulau-Pulau Kecil

\section{ANALISIS DAN ALTERNATIF SOLUSI/PENANGANAN}

1. Penduduk 
a. Jumlah dan Sebaran Penduduk Jumlah penduduk Provinsi Bali menurut hasil Sensus Penduduk tahun 2010 adalah 3.890 .757 jiwa.Sedangkan jumlah penduduk tahun 2015 sebanyak 4.152 .800 jiwa. Jumlah penduduk menurut kabupaten/kota berkisar 175.700- 880.600 jiwa, terkecil di Kabupaten Klungkung dan terbanyak di Kota Denpasar. Kepadatan rata-rata penduduk tahun 2015 adalah 737 jiwa $/ \mathrm{km}^{2}$. Kepadatan menurut kabupaten/ kota berkisar $323-6892 \mathrm{jiwa} / \mathrm{km}^{2}$, terendah di Kabupaten Jembrana dan tertinggi di Kota Denpasar (BPS 2017).

Jumlah penduduk di WP3K Provinsi Bali yang tersebar pada delapan kabupaten/kota atau 35 kecamatan pesisir pada tahun 2015 adalah 2.703.250 jiwa atau 65,09\%. Jumlah penduduk WP3K menurut kabupaten/kota berkisar 175.700 - 529.880 jiwa, terbanyak di Kabupaten Buleleng dan terkecil di Kabupaten Klungkung. Sedangkan jumlah penduduk menurut kecamatan berkisar 19.270 - 279.640 orang, penduduk terbanyak di Kecamatan Denpasar Selatan, Kota Denpasar dan terkecil di Kecamatan Selemadeg Barat, Kabupaten Tabanan (BPS 2017).

Kepadatan penduduk rata-rata WP3K adalah 770 jiwa $/ \mathrm{km}^{2}$, lebih besar dibandingkan dengan kepadatan penduduk Provinsi Bali secara keseluruhan. Kepadatan penduduk WP3K menurut kabupaten/kota berkisar 323-5940 jiwa $/ \mathrm{km}^{2}$, tertinggi di Kota Denpasar dan terendah di Kabupaten Jembrana. Sedangkan kepadatan penduduk menurut kecamatan berkisar $160-6708$ jiwa $/ \mathrm{km}^{2}$, tertinggi di Kecamatan Denpasar Timur dan terendah di Kecamatan Selemadeg Barat. Wilayah pesisir dan pulau-pulau kecil dengan kepadatan penduduk relatif tinggi terdapat di Kota Denpasar, Kabupaten Badung dan Gianyar (BPS 2017).

b. Pertumbuhan Penduduk

Selain sebaran penduduk yang tidak merata, masalah kependudukan lainnya di Bali adalah lajupertumbuhan penduduk yang tinggi dan cenderung semakin meningkat dari tahun ke tahun. Berdasarkan hasil Sensus Penduduk (SP) tahun 1980, laju pertumbuhan penduduk dalam periode 1971-1980 rata-rata 1,69\% pertahun. Hasil SP tahun 1990, laju pertumbuhan penduduk dalam peridoe 1980-1990 rata-rata 1,18\% pertahun. Hasil SP tahun 2000, laju pertumbuhan penduduk periode 1990-2000 rata-rata $1,19 \%$ pertahun. Pertumbuhan penduduk Provinsi Bali mengalami akselerasi selama periode 2000-2010 yaitu dengan laju pertumbuhan rata-rata 2,14\% pertahun.

Semua kabupaten/kota mengalami peningkatan laju pertumbuhan penduduk dalam periode 2000-2010 dibandingkan periode sebelumnya. Selama periode 20002010, pertumbuhan penduduk tertinggi terdapat di Kabupaten Badung yaitu 4,62\% 
pertahun. Pertumbuhan penduduk di Kota Denpasar juga tergolong sangat tinggi yaitu $4,01 \%$ pertahun. Posisi tertinggi ketiga diduduki Kabupaten Gianyar sebesar 1,80\% pertahun. Hal ini menunjukkan bahwa selain faktor kelahiran dan kematian, faktor migrasi masuk penduduk ke kabupaten/kota tersebut menjadi masalah penting dalam mempengaruhi tingginya pertumbuhan penduduk di wilayah tersebut yang tentunya sangat terkait dengan ketidakmerataan pembangunan, terutama pembangunan ekonomi yang masih terpusat di wilayah Bali bagian selatan.

c. Proyeksi Jumlah dan Kepadatan Penduduk

Berdasarkan laju pertumbuhan penduduk menurut Hasil Sensus Penduduk Tahun 2010 dan tahun dasar 2015, jumlah penduduk di WP3K Provinsi Bali pada tahun 2038 diproyeksikan sebanyak 4.861.799 orang. Proyeksi jumlah penduduk menurut kabupaten/kota berkisar 214.182 1.839.043 orang dimana penduduk terbanyak diKabupaten Badung dan terendah di Klungkung. Kabupaten Badung merupakan kabupaten dengan pembangunan pariwisata yang paling maju di Bali, menghadapi masalah terkait dengan tingginya arus penduduk pendatang. Sedangkan proyeksi jumlah penduduk menurut kecamatan berkisar 21.303 838.349 orang, terbanyak di Kecamatan Kuta Selatan, Kabupaten Badung dan terendah di Kecamatan Selemadeg, Kabupaten Tabanan (BPS 2017)..

Sementara itu, kepadatan penduduk rata-rata di WP3K Provinsi Bali pada tahun 2038 diproyeksikan sebesar 1384 orang $/ \mathrm{km} 2$. Proyeksi kepadatan penduduk menurut kabupaten/kota berkisar4079.978 orang $/ \mathrm{km} 2$, dimana penduduk terpadat di Kota Denpasar dan terendah di Kabupaten Jembrana. Kepadatan penduduk menurut kecamatan berkisar 185-18.120 orang $/ \mathrm{km}^{2}$. Penduduk terpadat diproyeksikan di Kecamatan Kuta Kabupaten Badung dan terendah di Kecamatan Selemadeg Kabupaten Tabanan.

2. Budaya

a. Masyarakat Hukum Adat

Masyarakat Hukum Adat di Bali dilegalisasi berdasarkan Peraturan Daerah Provinsi Bali No. 3 Tahun 2001 tentang Desa Pakraman, sebagaimana diubah dengan Perda No. 3 Tahun 2003. Menurut Perda ini, Desa Pakraman adalah kesatuan masyarakat Hukum Adat di Provinsi Bali yang mempunyai satu kesatuan tradisi dan tata krama pergaulan hidup masyarakat umat Hindu secara turun temurun dalam ikatan Kahyangan Tiga atau Kahyangan Desa yang mempunyai wilayah tertentu dan harta kekayaan sendiri serta berhak mengurus rumah tangganya sendiri. Masing-masing Desa Pakraman memiliki 
aturan tersendiri yang disebut Awig-awig Desa Pakraman.

Secara umum Desa Pakraman mempunyai identitas, eksistensi, peranan dan kewajiban-kewajiban yang dibangun atas dasar konsep Tri Hita Karana (Peters dan Wardana 2013), yaitu unsur Parahyangan (keterikatan terhadap tempat pemujaan yang sama), unsur Pawongan (keterikatan terhadap sesama warga atau krama adat khususnya yang beragama Hindu), dan unsur Palemahan (keterikatan terhadap wilayah teritorial).

Jumlah Desa Pakraman di Provinsi Bali pada tahun 2015 adalah 1.492 buahdengan rincian menurut kabupaten/kota berkisar 35-344 buah. Desa Pakraman di wilayah pesisir dan pulau-pulau kecil berjumlah 772 buah atau 51,74\%. Mengingat seluruh wilayah Provinsi Bali merupakan wilayah Desa Adat (Desa Pakraman) maka seluruh WP3K Provinsi Bali juga merupakan kesatuan masyarakat Hukum Adat.

Disamping Desa Adat, masyarakat Hukum Adat secara khusus di WP3K yang diakui keberadaannya yaitu Bendega berdasarkan Perda Provinsi Bali No. 11 Tahun 2017 tentang Bendega. Menurut Perda ini, Bendega adalah lembaga tradisional di bidang kelautan dan perikanan pada masyarakat adat di Bali yang ada di wilayah pesisir, bersifat ekonomi, sosial, budaya dan religius yang secara historis terus tumbuh dan berkembang sesuai dengan budaya dan kearifan lokal Bali.

Bendega secara kongkrit tersebar di sentra-sentra nelayan di seluruh Bali. Masing-masing Lembaga Bendega memililki Palemahan, Pawongan dan Parhyangan. Palemahan dapat berwujud secara fisik dalam bentuk lokasi/tempat pemangkalan perahu yang ada di pantai dan laut sekitarnya. Pawongan dapat berwujud dalam bentuk krama (warga masyarakat kelautan dan perikanan atau semisal nelayan). Sedangkan Parhyangan berwujud dalam bentuk Pura Segara (Pura Swagina untuk memuja Tuhan dalam manifestasinya sebagai Penguasa Laut).

Berdasarkan Perda di atas maka seluruh tempat-tempat pemangkalan nelayan di seluruh Bali yang memenuhi 3 syarat yaitu adanya Palemahan (Ruang), Pawongan (Warga/Anggota) dan Parhyangan (Pura Segara) merupakan kesatuan masyarakat Hukum Adat yang diakui eksistensinya oleh negara.

b. Pantai dan Laut sebagai Kawasan Suci Agama Hindu dalam kitab sucinya yaitu Weda telah menguraikan tentang apa yang disebut dengan tempat-tempat suci. Bagi umat Hindu di Bali, pantai dan laut diyakini memiliki nilai-nilai kesucian, di samping gunung, danau, dan campuhan (pertemuan sungai). Oleh karena itu pura dan tempat-tempat suci umumnya didirikan di tempat tersebut, karena di tempat itu 
orang-orang suci dan umat Hindu mendapatkan pikiran-pikiran suci (wahyu). Begitu juga berbagai jenis upacara keagamaan dilakukan di pantai dan laut.

Selain itu, banyaknya tempat-tempat suci (pura) yang didirikan di pantai maka kesucian pantai mutlak harus dipertahankan. Tempat-tempat suci tersebut memiliki radius kesucian yang disebut Kekeran dengan ukuran Apeneleng, Apanimpug, dan Apenyengker tergantung pada tingkatan dari tempat suci (pura) tersebut. Sebagai kawasan suci, pantai dan laut difungsikan sebagai tempat melangsungkan berbagai upacara keagamaan. Upacara keagamaan Umat Hindu dilangsungkan di pantai dan laut yaitu: upacara Candi Narmada, Melasti, Nyegara Gunung, Nganyud, Mulong Pekelem, Banyu Pinaruh, Ngangkid, Melukat, dan lain-lain.

3. Ekonomi Wilayah

a. Struktur Perekonomian

Secara kewilayahan, share perekonomian Daerah Bali masih didominasi oleh wilayah Bali Selatan yaitu posisi pertama ditempati oleh Kabupaten Badung berkontribusi sebesar 23,39\%, posisi kedua ditempati oleh Kota Denpasar berkontribusi sebesar $21,80 \%$ dan posisi yang ketiga dan keempat ditempati oleh wilayah Bali Utara yaitu Kabupaten Buleleng sebesar 14,45\%. Kabupaten Bangli merupakan kabupaten yang paling rendah kontribusinya terhadap pembentukan nilai tambah PDRB baik secara nominal maupun secara ril yaitu sebesar 2,83\%. Kontribusi Kabupaten Tabanan, Karangasem, Jembrana dan Klungkung juga relatif rendah kontribusinya terhadap perekonomian provinsi yaitu masingmasing 9,75\%, 6,97\%, 5,82\% dan 3,63\%. Kondisi ini dapat menandakan masih ada ketimpangan pembangunan antar kabupaten/kota di Bali, karena pusat perekonomian cendrung masih terpusat.

Selama periode 2011-2015, kontribusi sektor primer terhadap pembentukan PDRB Provinsi Bali rata-rata 16,59\%, sektor sekunder rata-rata $16,26 \%$ dan sektor tersier rata-rata $67,16 \%$. Pada sektor primer, kontribusi terbesar adalah sektor pertanian dalam arti luas yaitu rata-rata 15,34\%. Kontribusi sektor primer kecenderungannya mengalami penurunan dari waktu kewaktu, kontribusi sektor sekunder berfultuasi kecil sedangkan sektor tersier cenderung meningkat walaupun pada tahun 2015 sedikit menurun dibandingkan tahun sebelumnya.

Dilihat dari lapangan usaha, kontribusi terbesar terhadap pembentukan PDRB tahun 2015 adalah Penyediaan Akomodasi dan Makan Minum. Selama periode 2011-2015, lapangan usaha ini meningkat dari 19,37\% tahun 2011 sampai 23,10\% tahun 2014 akan tetapi menurun di tahun 2015 menjadi 22,82\%. Kontribusi 
terbesar kedua diduduki oleh Pertanian, Kehutanan dan Perikanan. Kotribusi lapangan usaha ini pada tahun 2011 sebesar $16,23 \%$ dan terus menurun hingga menjadi 14,64\% pada tahun 2014, dan pada tahun 2015 sedikit meningkat menjadi 14,92\%. Peternakan dan Perikanan merupakan dua kategori pada lapangan usaha Pertanian, Kehutanan dan Perikanan yang memberikan kontribusi terbesar bagi pembentukan PDRB yaitu masing-masing dengan rata-rata $4,63 \%$ dan $4,22 \%$ dalam periode 2011-2015.

Struktur perekonomian kabupaten/ kota di Bali juga menunjukkan dominasi kelompok sektor tersier akan tetapi dominasi sektor tersier di Kota Denpasar dan Kabupaten Badung telah melampaui angka di atas 75\%. Sementara kontribusi sektor primer menurut kabupaten/kota berkisar 7,0-30,2\%, tertinggi di Kabupaten Karangasem dan terendah di Kabupaten Badung.

\section{b. Pertumbuhan Ekonomi}

Menurut BPS 2016, Pergerakan pertumbuhan ekonomi Bali dalam periode 2011-2015 berfluktuasi dengan rata-rata pertumbuhan pertahunnya sebesar $6,62 \%$. Pada tahun 2011, ekonomi Bali tumbuh 6,66\%, kemudian terjadi peningkatan fluktuatif sampai tahun 2014 menjadi sebesar 6,73\% akan tetapi tahun 2015 menurun menjadi 6,04\%. Sebagai daerah yang mengandalkan sektor pariwisata, pertumbuhan ekonomi Bali sangat dipengaruhi oleh perlambatan pertumbuhan jumlah kunjungan wisatawan mancanegara ke Bali. Pada tahun 2014, pertumbuhan kunjungan wisatawan ke Bali sebesar 14,89\% dan pada tahun 2015 pertumbuhannya hanya 6,24\%. Pertumbuhan ekonomi Bali juga tidak terlepas dari kondisi global dimana terjadi penurunan harga komoditas yang berdampak pada penurunan nilai ekspor.

Selama periode 2011-2015, pertumbuhan ekonomi Bali selalu berada di atas laju pertumbuhan ekonomi nasional. Selama periode tersebut, laju pertumbuhan ekonomi nasional terus menurun dari 6,17\% tahun 2011 menjadi 4,79\% tahun 2015. Hal ini menunjukkan bahwa secara nasional pertumbuhan ekonomi Bali relatif lebih baik. Pada tahun 2013 dan 2014, pertumbuhan ekonomi Bali selalu tertinggi di wilayah JABALNUSRA. Akan tetapi pada tahun 2015, pertumbuhan ekonomi Bali dilangkahi oleh NTB yang tumbuh sebesar $21,24 \%$.

Jika dilihat pertumbuhan menurut lapangan usaha atau sektor, sektor pertanian mengalami penurunan pertumbuhan dari 4,63\% tahun 2014 menjadi 3,41\% tahun 2015. Selama periode 2011-2015, pertanian tumbuh rata-rata 3,13\% pertahun. Dengan sumbangan terhadap PDRB yang relatif besar yaitu rata-rata tahunan 15,34\% maka angka pertumbuhan sektorpertanian ini 
memberikan sumbangan yang signifikan terhadap pertumbuhan ekonomi. Penyediaan akomodasi dan makan minum sebagai penyumbang PDRB terbesar, tumbuh rata-rata tahunan sebesar 7,04\% dan laju pertumbuhannya tahun 2015 sebesar 5,76\%, menurun dari $6,82 \%$ di tahun 2014.

Lima lapangan usaha sebagai sumber pertumbuhan utama perekonomian Provinsi Bali tahun 2015 adalah Penyediaan Akomodasi dan Makan Minum yaitu sebesar 1,13\%, Perdagangan Besar dan Eceran, Reparasi Mobil dan Sepeda sebesar 0,68\%, Informasi dan Komunikasisebesar 0,64\%, Pettanian, Kehutanan dan Perikanan sebesar $\quad 0,51 \%$ dan Administrasi Pemerintahan, Pertahanan dan Jaminan Sosial Wajib sebesar $0,50 \%$.

\section{c. Pendapatan Per Kapita}

Pendapatan per kapita menggambarkan seberapa besar nilai tambah yang diciptakan/diterima tiap-tiap penduduk, sehingga secara tidak langsung akan menggambarkan tingkat kesejahteraan penduduk di wilayah bersangkutan. Semakin besar nilai PDRB per kapita maka dapat dikatakan semakin sejahtera atau makmur. Kendati demikian, PDRB per kapita merupakan angka agregat (rata-rata) sehingga masih sangat kasar jika dijadikan cerminan bagi tingkat kesejahteraan penduduk. Angka ini mengasumsikan semua penduduk mempunyai akses yang sama terhadap pendapatan, sehingga kurang tepat dalam mencerminkan kesejahteraan.

Pada tahun 2015, pendapatan per kapita Provinsi Bali atas dasar harga berlaku mencapai Rp. 42,66 juta, masih di bawah angka nasional yang mencapai Rp. 45,18 juta. Jika dibandingkan dengan tahun 2014, pendapatan per kapita atas dasar harga berlaku tahun 2015 mengalami kenaikan 11,97\%. Jika dilihat berdasarkan harga konstan, pendapatan perkapita Provinsi Bali tahun 2015 sebesar Rp. 31,10 juta, meningkat 4,82\% dibandingkan tahun 2014. Pertumbuhan pendapatan perkapita ini jauh lebih tinggi dibandingkan dengan laju pertumbuhan penduduk sebesar 1,17\%. Secara nasional, pendapatan perkapita Bali pada tahun 2015 berada pada ranking ke-11. Sedangkan di wilayah JABALNUSRA berada pada ranking ke-3 setelah DKI dan Jatim (BPS 2016).

Disparitas ekonomi antar kabupaten/ kota di Bali terlihat dari tingginya kesenjangan pendapatan perkapita. Pendapatan Perkapita Atas Dasar Harga Konstan menurut kabupaten/kota pada tahun 2015 berkisar Rp. 16,57 juta - Rp. 47,34 juta, tertinggi di Kabupaten Badung dan terendah Kabupaten Bangli. Pendapatan per kapita Kabupaten Badung hampir 3 kali lipat dari Kabupaten Bangli. Selain Badung, kabupaten/kota dengan pendapatan perkapita di atas provinsi yaitu Denpasar dan Gianyar. Sementara enam 
kabupaten lainnya di bawah angka provinsi.

Kondisi ini menunjukkan bahwa perekonomian Bali terpusat hanya di sebagian kecil kabupaten/kota.

\section{UCAPAN TERIMA KASIH}

Terima kasih penulis ucapkan kepada Gubernur Provinsi Bali, Kepala Dinas Kelautan dan Perikanan Provinsi Bali beserta seluruh jajarannya, Direktur Direktorat Perencanaan Laut KKP beserta seluruh jajarannya dan Kepala Badan Riset Sumberdaya Manusia Kelautan dan Perikanan (BRSDM-KP).

\section{REFERENSI}

[BPS] Badan Pusat Statistik. 2016. Provinsi Bali Dalam Angka 2016, Badan Pusat Statistik, Denpasar.

[BPS] Badan Pusat Statistik. 2017. Provinsi Bali Dalam Angka 2017, Badan Pusat Statistik, Denpasar.

Ditjen KKP. 2016. Tata Cara Penyusunan Peta Rencana Zonasi Wilayah Pesisir dan Pulau Pulau Kecil, Direktorat Perencanaan Ruang Laut, Direktorat Jenderal Pengelolaan Ruang Laut,
Kementerian Kelautan dan Perikanan, Jakarta.

Gordon, A.L. 2012. Brief ITF review; Pacific inflow into the Indonesian Seas, CLIVAR ITF -Task Team, Ancol, Indonesia.

[Sekda] Sekretaris Daerah Provinsi Bali. 2003. Peraturan Daerah Provinsi Bali No. 3 Tahun 2003 tentang Desa Pakraman, perubahan dari Perda No. 3 Tahun 2001.

[Sekda] Sekretaris Daerah Provinsi Bali. 2017. Perda Provinsi Bali No. 11 Tahun 2017 tentang Bendega.

[Setneg] Sekretariat Negara. 2014. UndangUndang Republik Indonesia Nomor 23 Tahun 2014 Tentang Pemerintahan Daerah.

[Setneg] Sektretariat Negara. 2014. UndangUndang Nomor 27 Tahun 2007 Jo Undang-Undang Nomor 1 Tahun 2014 tentang Pengelolaan Wilayah Pesisir dan Pulau-Pulau Kecil.

Supriatna, J. 2008. Melestarikan Alam Indonesia, Yayasan Obor Indonesia, Jakarta.

Peters, J.H, Wardana, W. 2013. Tri Hita Karana, Kepustakaan Populer Gramedia, Jakarta. 